\title{
Two new Brazilian isolates of Bacillus thuringiensis toxic to Anticarsia gemmatalis (Lepidoptera: Noctuidae)
}

\author{
Fiuza, LM. ${ }^{a *}$, Schünemann, R. ${ }^{a}$, Pinto, LMN. ${ }^{a}$ and Zanettini, MHB. ${ }^{b}$ \\ aPrograma de Pós-Graduação em Biologia, Laboratório de Microbiologia e Toxicologia, \\ Universidade do Vale do Rio dos Sinos - UNISINOS, Av. Unisinos, 950, CEP 93022-000, São Leopoldo, RS, Brazil \\ ${ }^{b}$ Departamento de Genética, Instituto de Biociências, Universidade Federal do Rio Grande do Sul - UFRGS, \\ CP 15053, CEP 91501-970, Porto Alegre, RS, Brazil \\ *e-mail: fiuza@unisinos.br
}

Received February 16, 2011 - Accepted June 14, 2011 - Distributed May 31, 2012

(With 3 figures)

\begin{abstract}
Bacillus thuringiensis is a bacterium used for biopesticides production and pest-resistant plants due to the synthesis of protein crystals by cry genes, which are effective in controlling several insect orders such as Lepidoptera. This work aimed at the evaluation and characterisation of two new B. thuringiensis isolates active against A. gemmatalis (Hübner 1818) larvae, which is the soybean major pest. The results showed that Bt117-4 isolate amplified fragments corresponding to cry 2 and cry 9 genes, and synthesised protein fragments equivalent to 130,90 and $45 \mathrm{kDa}$. The Bt3146-4 isolate amplified DNA fragments corresponding to cry9 gene and synthesised protein fragments of 70, 58 and $38 \mathrm{kDa}$. Transmission electron microscopy revealed the presence of protein crystals in both isolates. $\mathrm{CL}_{50}$ with Cry purified proteins from Bt117-4 and Bt3146-4, corresponded to 0.195 and $0.191 \mu \mathrm{g}$ larvae ${ }^{-1}$, respectively. The two $B$. thuringiensis isolates selected in this study were effective to control velvetbean caterpillar at laboratory conditions. Field tests should be carried on to develop new biopesticides formulation as well for cry genes resource for Anticarsia gemmatalis resistant transgenic plants.
\end{abstract}

Keywords: Lepidoptera, velvetbean caterpillar, cry genes, Bacillus thuringiensis.

\section{Dois novos isolados brasileiros de Bacillus thuringiensis tóxicos para Anticarsia gemmatalis (Lepidoptera: Noctuidae)}

\section{Resumo}

Bacillus thuringiensis é uma bactéria utilizada na produção de biopesticidas e de plantas resistentes às pragas por causa da síntese de cristais proteicos pelos genes cry, os quais são eficazes no controle de diversas ordens de insetos, como os lepidópteros. O presente trabalho objetivou a avaliação e a caracterização de dois novos isolados de B. thuringiensis ativos contra lagartas de $A$. gemmatalis (Hübner 1818), que é a principal praga da cultura da soja. Os resultados obtidos revelaram que o isolado Bt117-4 amplificou fragmentos correspondentes aos genes cry 2 e cry 9 , sendo que os fragmentos proteicos sintetizados foram equivalentes a 130, 90 e $45 \mathrm{kDa}$. O isolado Bt3146-4 amplificou fragmentos de DNA que correspondem ao gene cry9 e sintetizou fragmentos proteicos de 70, 58, e $38 \mathrm{kDa}$. Os dados de microscopia eletrônica de transmissão revelam a presença de cristais proteicos em ambos os isolados. $\mathrm{A} \mathrm{CL}_{50}$, com proteínas Cry purificadas de Bt117-4 e Bt3146-4, correspondeu a 0,195 e 0,191 $\mu$ g lagarta ${ }^{-1}$, respectivamente. Os dois isolados de B. thuringiensis selecionados neste trabalho mostraram-se eficientes no controle da lagarta-da-soja em laboratório, sendo recomendada sua avaliação a campo para posterior aplicação na formulação de biopesticidas ou como fonte de genes cry para a obtenção de plantas geneticamente modificadas resistentes à Anticarsia gemmatalis.

Palavras-chave: Lepidoptera, lagarta-da-soja, genes cry, Bacillus thuringiensis. 


\section{Introduction}

Biopesticides based on Bacillus thuringiensis have become a reliable tool in agricultural pest control, forestry and health-related conditions (Lopes et al., 2010). This gram-positive bacterium has been isolated worldwide and characterised by different techniques, including PCR screening to detect the cry genes. The efficiency of the insecticidal properties of $B$. thuringiensis is due to the synthesis of insecticidal crystal proteins (Cry proteins) encoded by the cry genes. Currently, more than 560 cry genes have been identified and classified into 68 classes based on the homology of their proteins (http://www. lifesci.sussex.ac.uk/home/Neil_Crickmore/Bt). Cry proteins have already been described as toxic to several insect from Lepidoptera, Diptera, Coleoptera, Hymenoptera, Homoptera, and Malophaga orders (Zhong et al., 2000; De Maagd et al., 2001; Castilhos-Fortes et al. 2002; Pinto et al. 2003; Martins et al., 2004; Nazarian et al., 2009; López-Pazos et al., 2009) and also to nematodes (Marroquin et al., 2000; Jouzani et al., 2008).

Cry proteins are produced in inactive form and, after ingestion by the susceptible insect, the crystal protein is solubilised by the intestinal alkaline $\mathrm{pH}$. After solubilisation, the protoxins are activated by intestinal proteases, yielding the activated form of Cry toxins. Then, the toxins bind to receptors of high affinity sites on the surface of epithelial cells of the midgut microvilli, which are turgid and burst due to formation of pores in the apical membranes (Grochulski et al., 1995; Bravo et al., 2004; Fiuza, 2004; Knaak et al., 2010).

In Brazil, Anticarsia gemmatalis Hübner 1818 (Lepidoptera, Noctuidae) is considered the key pest of soybean (Panizzi and Corrêa-Ferreira, 1997; Levy et al., 2004; Monnerat et al., 2007). A. gemmatalis, also known as velvetbean caterpillar, attack the aerial parts of plants (Gallo et al., 2002), hampering their development and thus causing losses in grain production (Morales et al., 1995). The control of this pest can occur naturally under favourable conditions, through presence of natural enemies. When this does not happen, the use of insecticides with high applications per crop, is designed to avoid loss in yield (Moscardi, 1993). Currently, many adverse factors interfere in the velvetbean caterpillar control, such as the environmental impact that pesticides cause to other unrelated species and even to its natural enemies. In this research, the delta-endotoxins of two new isolates of $B$. thuringiensis that synthesize insecticidal proteins active against the target insect were tested, as the variability of cry genes and morphological crystals structure from these isolates can be applied in soybean pest management programs, aiming for the A. gemmatalis control.

\section{Material and Methods}

\subsection{B. thuringiensis isolates}

The $B$. thuringiensis isolates tested in this work belong to the Bank of Entomopathogenic Bacteria from the
Laboratory of Microbiology and Toxicology (UNISINOS). They were isolated from soil samples collected in free biopesticides agricultural areas of southern Brazil. The isolates Bt117-4 and Bt3146-4, which showed a mortality of $78 \%$ and $100 \%$, respectively, were previously evaluated against third-instar larvae of A. gemmatalis using bacterial suspensions with $1.10^{9}$ cells $\mathrm{mL}^{-1}$. The mortality was evaluated within three different generations, using 20 larvae per treatment, until the $7^{\text {th }}$ day after treatment application, and then corrected by Abbott's formula (1925). The strain B. thuringiensis kurstaki HD1 (Institut Pasteur, Paris) was used as positive control.

\subsection{Electron microscopy}

The bacterial and paraesporal inclusion body ultrastructures were evaluated at the Electron Microscopy Centre (UFRGS, Brazil). The selected isolates in bioassays were grown in solid Usual Medium (UM) (De Barjac and Lecadet, 1976) supplemented with glucose, and bacterial aliquots were fixed in Karnowsy's pH 7.4 (0.1 M phosphate buffer, $8 \%$ paraformaldehyde and $25 \%$ glutaraldehyde) and post-fixed in osmium tetroxide $(2 \%)$. The samples were dehydrated in increasing acetone solutions (30-100\%) and subsequently impregnated with resin (Arauditidurcopan ACM). The blocks were cut with ultramicrotome (Leica) and compared with $7 \%$ uranyl acetate for subsequent observation in transmission electron microscopy (Zeiss EM900).

\subsection{Cry genes}

B. thuringiensis isolates were cultured for 12 hours at $30{ }^{\circ} \mathrm{C}$ on Nutrient Agar $\left(3 \mathrm{~g} \mathrm{~L}^{-1}\right.$ peptone, $5 \mathrm{~g} \mathrm{~L}^{-1}$ meat extract, $0.5 \mathrm{~g} \mathrm{~L}^{-1}$ albumin extract, $0.006 \mathrm{~g} \mathrm{~L}^{-1} \mathrm{MnCl} 2,0.08 \mathrm{~g} \mathrm{~L}^{-1}$ $\mathrm{CaCl}_{2}, 0.07 \mathrm{~g} \mathrm{~L}^{-1} \mathrm{MgCl}_{2}$ and $1.5 \mathrm{~g} \mathrm{~L}^{-1}$ agar), then were subjected to total DNA extraction, according to the method described by Hansen and Hendriksen (2001). The primers for amplification of DNA fragments corresponding to cryl were: Un1(d), 5'-CATGATTCATGCGGCCAGATAAAC-3', Uni1(r), 5'-TTGTGACACTTCTGCTTCCCATT-3' (Ben-Dov et al., 1997); cry2: Un2(d), 5'-GTTATTCTTAATGCAGATGAATGGG-3' Un2(r), 5'-CGGATAAAATAATCTGGGAAATAGT-3' (Ben-Dov et al., 1997), cry9: Un9(d), 5'-CGGTGTTACTATTAGCGAGGGCGG-3', Un9(r), 5'-GTTTGAGCCGCTTCACAGCAATCC-3' (BenDov et al., 1999); to specific cry genes: Cry2Aa: Un2(d) 5'-GTTATTCTTAATGCAGATGAATGGG-3', EE-2Aa(r) 5'-GAGATTAGTCGCCCCTATGAG-3'; Cry2Ab: EE-2Ab(r) 5'-TGGCGTTAACAATGGGGGGAGAAAT-3'; Cry2Ac: EE-2Ac(r) 5'-GCGTTGCTAATAGTCCCAACAACA-3' (Ben-Dov et al., 1997) e Cry9A: EB-9A(d) 5'-GGTTCACTTACATTGCCGMGTTAGC-3', Un9(r) 5'-GTTTGAGCCGCTTCACAGCAATCC-3'; Cry9B: EB-9B(d) 5'-GCAAATGCATTTAGCGCTGGTCAA-3'; Cry9C: EB-9C(d) 5'-CCACCAGATGAAAGTACCGGAAG-3'; Cry9D: EB-9D(d) 5'-GCAATAAGGGTGTCGGTCACTGG-3' (Ben-Dov et al., 1999). 
Each Polymerase Chain Reaction (PCR) was performed with a final volume of $25 \mu \mathrm{L}$, using: $1 \mu \mathrm{L}$ of DNA sample with reaction buffer (10 mM TrisCl, 1mM EDTA); $0.2 \mathrm{mM}$ dNTP; 0.2 a $0.5 \mu \mathrm{M}$ of each primer and $0.5 \mathrm{U}$ of Taq DNA polimerase (GIBCO-BRL). The amplification was performed in thermal cycler set at 35 cycles for each reaction, with 1 minute denaturation at $95{ }^{\circ} \mathrm{C}$, annealing to primers for 1 minute at $52^{\circ} \mathrm{C}$ and extension for 1 minute at $72{ }^{\circ} \mathrm{C}$. A 5 minutes final extension at $72{ }^{\circ} \mathrm{C}$ was added. The strains $B$. thuringiensis kurstaki $\mathrm{HD} 1$ and $B$. thuringiensis aizawai type 1 were used as positive control and reactions without DNA addition as negative controls. PCR products amplified were analysed in agarose gel $(1.5 \%)$.

\subsection{Purification of ICPs}

To purify the Insecticidal Crystal Proteins (ICPs) from $B$. thuringiensis, the selected isolates were grown in $\mathrm{UM}$ for 48 hours at $28^{\circ} \mathrm{C}$ and $180 \mathrm{rpm}$. The suspensions with spores, crystals and cells were homogenised in phosphate buffer, pH 6.0 (0.1 $\mathrm{M} \mathrm{NaH}_{2} \mathrm{PO}_{4} \cdot \mathrm{H} 2 \mathrm{O} ; 100$ $\mathrm{mM}$ phenylmethanesulfonyl fluoride) and centrifuged at $28.000 \mathrm{~g}$ at $4{ }^{\circ} \mathrm{C}$. The suspensions were washed twice with autoclaved distilled water by centrifugation at $7.000 \mathrm{~g}$ for 15 minutes, and then the crystal purification was performed in sucrose gradient from 67 to $78 \%$. The pellet containing the purified crystals was solubilised according to Fiuza (1995) and $15 \mu \mathrm{L}$ of the Cry proteins were analysed by SDS-PAGE (Laemmli, 1970) and stained with Coomassie blue. The protein concentration was determined according to the Bradford method (1976). The molecular weight was estimated by comparison with the marker Hig Range (Gibco-BRL).

\subsection{Insects}

A. gemmatalis larvae were collected from soybean fields in southern Brazil. After the quarantine period, healthy adults were introduced into the insect rearing. In addition to the specimens obtained in the field, two other lots were supplied by the Entomology Laboratory of the National Center for Soybean Research (EmbrapaSoja, Londrina-PR). A. gemmatalis was maintained in the laboratory at $25 \pm 2{ }^{\circ} \mathrm{C}, 12$ hours photoperiod, $70 \%$ relative humidity $(\mathrm{RH})$, and the larvae were reared on an artificial diet described by Greene et al. (1976).

\subsection{Bioassays}

Cry proteins from $B$. thuringiensis isolates were evaluated in second-instar larvae of $A$. gemmatalis. The range of tested protein concentrations was established in a pilot test. After, $10 \mu \mathrm{L}$ of six different concentrations (3.0, 1.5, 0.75, $0.37,0.18$ and $\left.0.09 \mu \mathrm{g} \mathrm{mL} \mathrm{m}^{-1}\right)$ were applied on soybean leaf discs ( $0.8 \mathrm{~cm}$ diameter) and placed individually in acrylic mini-plates. Each treatment consisted of 30 insects and three replicates. As the insect was consuming the entire soybean disc, it was replaced by another disc without the addition of $B$. thuringiensis protein.

In control, the suspensions were replaced by sodium phosphate buffer $100 \mathrm{mM}, \mathrm{pH}$ 6.0. A total of 1260 insects were used, where the replicates consisted of different insect generations. The experiments were kept in the same rearing conditions and evaluations were performed daily until the $5^{\text {th }}$ day after treatment. The mean lethal concentration $\left(\mathrm{LC}_{50}\right)$ was estimated by Probit analysis using Polo-PC program LeOra Software, 1987 (Haddad, 1998).

\section{Results}

\subsection{Characterisation of $B$. thuringiensis isolates}

The transmission electron microscopy analysis showed the presence of protein crystals in both isolates, where the Bt117-4 isolate crystal (Figure 1a) had a cuboidal aspect, while the Bt3146-4 (Figure 1b) showed a spherical shape.

\subsection{Crystal protein analysis}

The protein profile analysis from Bt117-4 and Bt3146-4 isolates, held on SDS-PAGE (10\%), revealed that Bt1174 isolate synthesizes protein fragments of $\sim 130,90$ and $45 \mathrm{kDa}$ and Bt3146-4 synthesises peptides of $\sim 70,58$, and $38 \mathrm{kDa}$ (Figure 2).

\subsection{Cry genes}

PCR amplification (Figure 3) did not show fragments with molecular weights expected for cryl genes (Ben-Dov, et al., 1997 ) in both isolates. However, isolates evaluation with primers corresponding to cry9 genes (Ben-Dov et al., 1999) revealed $400 \mathrm{bp}$ fragments, which correspond to this class of genes. In Bt117-4 isolate, a 725 pb fragment was amplified, corresponding to molecular weight of $c r y 2$
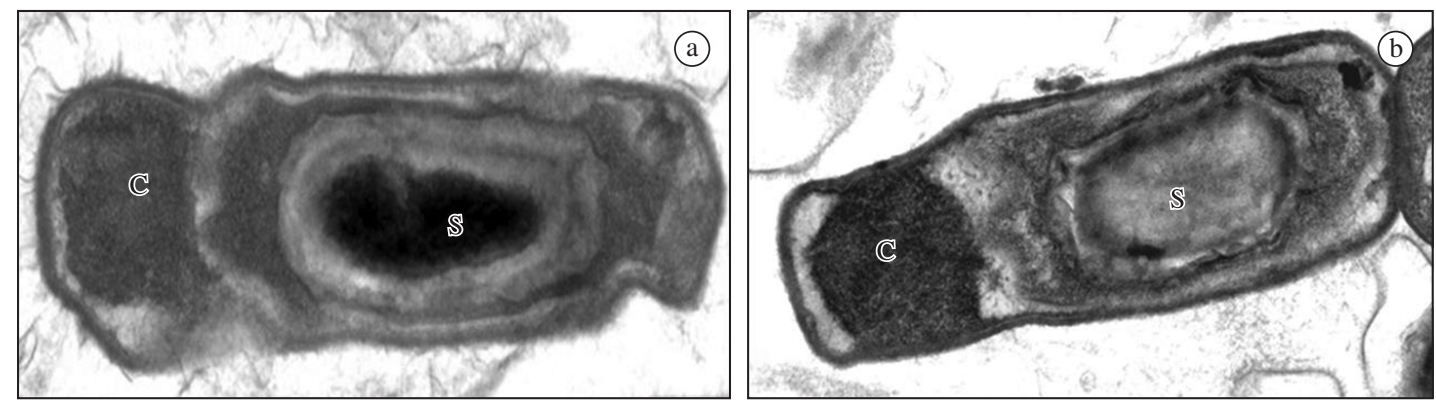

Figure 1. Transmission electron microscopy of Bacillus thuringiensis isolates: (a) Bt117-4, (b) Bt3146-4, (s) spore and (c) crystal. Magnification 40.000x. 
genes (Ben-Dov, et al., 1997), which was not amplified in the Bt3146-4 isolate. The primers analysis specific for cry 2 and cry 9 genes is showed in Table 1.

\section{4. $C L_{50}$ of Cry proteins}

The Bt117-4, Bt3146-4 and Bt kurstaki HD1 strains showed a $\mathrm{LC}_{50}$ of $0.195,0.191$ and $0.082 \mu \mathrm{g} /$ larvae, respectively, on the fifth day after the treatment (DAT) (Table 2).

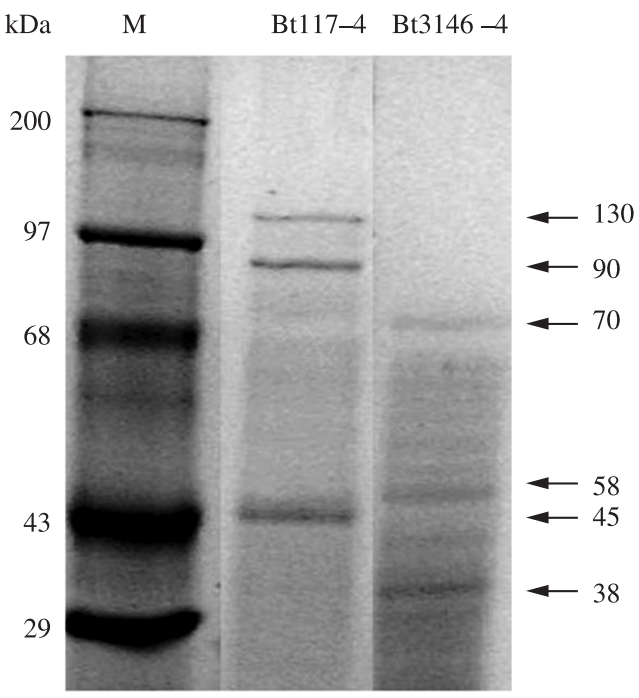

Figure 2. SDS-PAGE (10\%) analysis of solubilised toxins from Bacillus thuringiensis isolates. $M$ indicates de molecular mass marker. Sizes of protein bands $(\mathrm{kDa})$ are indicated by arrows.

\section{Discussion}

Some research (Bobrowski et al., 2001; Silva et al., 2004; Monnerat et al., 2007; Silva-Werneck and Ellar, 2008; Gobatto et al., 2010) has shown the possibility of finding $B$. thuringiensis native isolates with toxicity to A. gemmatalis. The bioassays screening results with new $B$. thuringiensis isolates are useful for local and regional insect pest management. For example, in studies with B. thuringiensis kurstaki strains, Mascarenhas et al. (1998) and Dias et al. (1999) found different mortality rates for the same species.

Regarding the crystal shape analogy and its specific toxicity to insect orders, Taylor et al. (1992), Bernhard et al. (1997), and Habib and Andrade (1998) observed that the crystal shape can provide information on the insecticidal activity of a strain. In this study, the toxic isolate Bt1174 showed cuboidal crystals, which are known to contain proteins toxic to Lepidoptera (Dankocsik et al., 1990; Wu et al. 1991; Monnerat et al., 2007; Silva-Werneck and Ellar, 2008).

The SDS-PAGE protein profiles analysis of Bt117-4 and $B t 3146-4$ isolates showed that the solubilised samples are composed of different protein fragments (Figure 2) and this may be related to the different gene profiles obtained from the two analysed samples. Cry9 proteins have around $130 \mathrm{kDa}$, and Cry 2 proteins are known to have a molecular weight below $90 \mathrm{kDa}$ (Crickmore et al., 1998). These protein profiles were observed in the $B t 117-4$ isolate and it can be related to the cry 9 and cry 2 genes, detected by PCR. Regarding the Bt3146-4 isolate, its proteins may be codified by new cry genes that were not identified with the

$\mathrm{pb}$
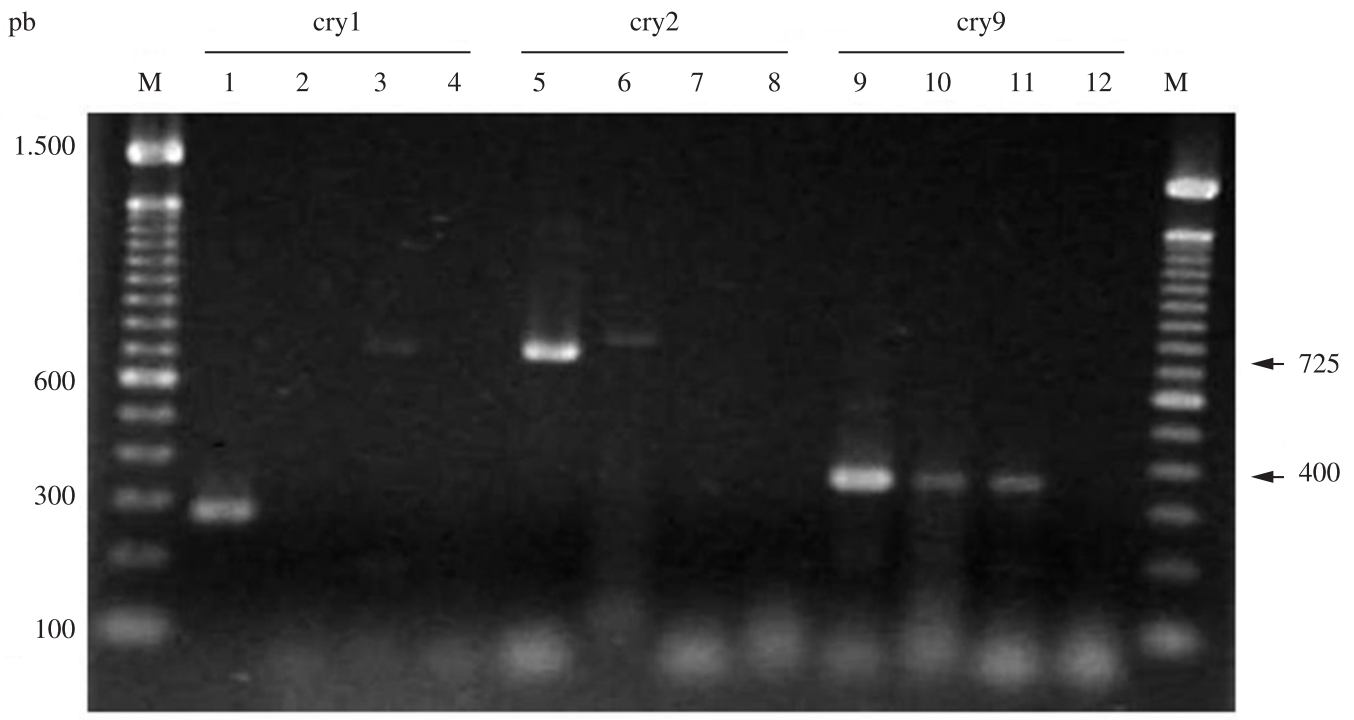

Figure 3. Agarose gel (1.5\%) electrophoresis of PCR products amplified from B. thuringiensis isolates, with primers to cryl, cry2 and cry9 genes. Lanes: (1, 5) B. thuringiensis kurstaki HD1; (9) B. thuringiensis aizawai type 1; (2, 6, 10) Bt117-4; (3, $7,11)$ Bt3146-4; $(4,8,12)$ negative control. M, molecular weight marker (100 bp, Gibco BRL). Arrows indicates expected product length. 
Table 1. Profile of cry genes in Bacillus thuringiensis isolates, determined by PCR.

\begin{tabular}{|c|c|c|c|c|}
\hline \multirow{2}{*}{ Genes } & \multicolumn{4}{|c|}{ B. thuringiensis isolates } \\
\hline & Bt 117-4 & Bt 3146-4 & Bt kurstaki HD1 & Bt aizawai type 1 \\
\hline $\operatorname{cry} 2 A a$ & + & - & + & + \\
\hline $\operatorname{cry} 2 A b$ & + & - & + & - \\
\hline $\operatorname{cry} 2 A c$ & + & - & + & - \\
\hline $\operatorname{cry} 9 A$ & + & + & - & + \\
\hline $\operatorname{cry} 9 B$ & - & - & - & + \\
\hline
\end{tabular}

Table 2. Mean Lethal Concentration $\left(\mathrm{LC}_{50}\right)$ of Bacillus thuringiensis Cry proteins for Anticarsia gemmatalis second-instar larvae.

\begin{tabular}{cccc}
\hline \multirow{2}{*}{ Isolates } & \multicolumn{3}{c}{ LC $_{50}\left(\mu\right.$ larvae $\left.^{-1}\right)$} \\
\cline { 2 - 4 } & 5 DAT * & Confidence limits $(\mathbf{9 5 \%})^{\text {Slope } \pm \text { SEM }}$ \\
\hline Bt $117-4$ & 0.195 & $(0.024-0.373)$ & $0.575 \pm 0.205$ \\
Bt $3146-4$ & 0.191 & $(0.071-0.405)$ & $0.750 \pm 0.211$ \\
Bt kurstaki HD-1 & 0.082 & $(0.056-0.105)$ & $0.512 \pm 0.672$ \\
\hline
\end{tabular}

*DAT $=$ days after treatment.

used set of primers of this study. The protoxins from the Bt3146-4 isolate did not present the corresponding bands of Cry9 proteins in SDS-PAGE, which could indicate that $\operatorname{cry} 9$ genes detected by PCR are silent in this isolate.

Similar data were described by Pinto and Fiuza (2003) in tests performed with $B$. thuringiensis strains active against Lepidoptera, Coleoptera and Hymenoptera.

PCR analyses showed that Bt117-4 isolate harbours more than one class of cry genes, which DNA amplified fragments correspond to cry 2 and cry 9 genes. Estruch et al. (1997) and Liao et al. (2002) described that the action spectrum of different $B$. thuringiensis strains depends on the Cry proteins combination present in the crystal, which are encoded by different cry genes.

Bravo et al. (1998), by analysing cry genes diversity, found several combinations of these genes, however only $2.6 \%$ of the evaluated Mexican strains had cry 9 genes.

On the other hand, Pinto et al. (2003) showed that the $B$. thuringiensis strains isolated from southern Brazil presented a high frequency of cry9 genes (47\%). The data described by these authors and the results presented here were congruent, once the $B$. thuringiensis strains were obtained from the same region. The isolates evaluated in this study revealed the simultaneous presence of $c r y 2$ and cry9 genes, differing from Wang et al. (2003) who did not find both cry 2 and cry 9 genes in the same isolate. In another study, Ben-Dov et al. (1999) described strains from Israel, Kazakhstan, and Uzbekistan that had simultaneously cry9 genes with cryl or cry 2 genes.

The most toxic proteins evaluated for Lepidoptera are encoded by cry 1 , cry 2 , and cry9 (Bravo et al., 1998; Crickmore et al., 1998). In order to control Choristoneura fumiferana Clemens (Lepidoptera: Tortricidae), Pang et al. (2002) showed that a genetically modified $B$. thuringiensis strain, with the $c r y 9 C a$ gene insertion, was four times more efficient than the B. thuringiensis kurstaki HD-1 strain, traditionally used in their control.

Several studies aiming to evaluate new $B$. thuringiensis strains against lepidopterans have been performed worldwide (Zhong et al. 2000; Uribe, et al. 2003; Polanczyk et al., 2003; Knaak et al. 2010). Despite the mode of action of this pathogen showing similarity to all Lepidoptera, the discovery of new $B$. thuringiensis strains becomes important to study specific toxicity to target insects. As a consequence, these new strains might promote the production of specific biopesticide formulated with different B. thuringiensis strains, which may contain new genes that encode new insecticidal proteins. These genes can also be used for the development of new insect resistant plants (De Guglielmo-Cróquer et al., 2010).

The current results show that Bt117-4 and Bt3146-4 isolates are highly pathogenic, and can be used in soybean genetic transformation to obtain A. gemmatalis resistant plants, or in commercial formulations of potentially active biopesticides to the target species studied.

\section{References}

ABBOTT, WS., 1925. A method of computing the effectiveness insecticides. Journal of Economic Entomology, vol. 18, p. 265-267.

BEN-DOV, E., ANG, Q., ZARITSKY, A., MANAHEROB, R., BARAK, Z., SCHENEIDER, B., KHAMRAEV, A., BAIZHANOV, M., GLUPOV, V. and MARGALITH, Y., 1999. Multiplex PCR screening to detect cry9 genes in Bacillus thuringiensis strains. Applied and Environment Microbiology, vol. 65, p. 3714-3716.

BEN-DOV, E., ZARITSKI, A., DAHAN, E., BARAK, Z., SINAI, R., MANASHEROB, R., KHAMRAEV, A., TROITSKAYA, E., DUBITSKY, A., BEREZINA, N. and MARGALITH, Y., 1997. Extended screening by PCR for seven cry-group genes from field-collected strains of Bacillus thuringiensis. Applied and Environment Microbiology, vol. 63, p. 4883-4890. 
BERNHARD, K., JARRET, P., MEADOWS, M., BUTT, J., ELLIS, DJ., ROBERTS, GM., PAULI, S., RODGERS, P. and BURGES, HD., 1997. Natural isolates of Bacillus thuringiensis: worldwide distributions, characterization, and activity against insect pests. Journal Invertebrate Pathology, vol. 70, p. 59-68. http://dx.doi.org/10.1006/jipa.1997.4669

BOBROWSKI, VL., PASQUALI, G., ZANETTINI, MHB. and FIUZA, LM., 2001. Detection of cry1 genes in Bacillus thuringiensis isolates from south of Brazil and activity against Anticarsia gemmatalis (Lepidoptera: Noctuidae). Brazilian Journal of Microbiology, vol. 32, p. 105-109.

BRADFORD, MM., 1976. A rapid and sensitive method for quantification of microgram quantities of protein utilizing the principle of protein-dye binding. Analytical Biochemistry, vol. 72, p. 248-254. http://dx.doi.org/10.1016/0003-2697(76)90527-3

BRAVO, A., GÓMEZ, J., CONDE, C., MUÑOZ-GARAY, J., SÁNCHEZ, M., ZHUANG, SS., GILL. and SOBERÓN, EM., 2004. Oligomerization triggers differential binding of a poreforming toxin to a different receptor leading to efficient interaction with membrane microdomains. Biochimica et Biophysica Acta, vol. 1667, p. 38-46. PMid:15533304. http://dx.doi.org/10.1016/j. bbamem.2004.08.013

BRAVO, A., SARABIA, S., LOPEZ, L., ONTIVEROS, H., ABARCA, C., ORTIZ, A., ORTIZ, M., LINA, L., VILLALOBOS, FJ., PENA, G., NUNES-VALDEZ, ME., SOBERÓN, M. and QUINTERO, R., 1998. Characterization of cryIII genes within a Bacillus thuringiensis strain collection. Applied and Environment Microbiology, vol. 64, p. 4965-4972. PMid:9835590. PMCid:90950.

CASTILHOS-FORTES R., MATSUMURA, ATS., DIEHL, E. and FIUZA, LM., 2002. Susceptibility of Nasutitermes ehrhardti (Isoptera: Termitidae) to Bacillus thuringiensis subspecies. Brazilian Journal of Microbiology, v. 33, n. 3. http://dx.doi.org/10.1590/ S1517-83822002000300006

CRICKMORE, N., ZEIGLER, DR., FEITELSON, J., SCHNEPF, E., VAN RIE, J., LERECLUS, D., BAUM, J. and DEAN, DH., 1998. Revision of the literature for the Bacillus thuringiensis pesticide crystal proteins. Microbiology Molecular and Biology Review, vol. 62, p. 807-813. PMid:9729610. PMCid:98935.

DANKOCSIK, C., DONOVAN, WP. and IANY, CS., 1990. Activation of a cryptic crystal protein gene of Bacillus thuringiensis subspecies kurstaki by gene fusion and determination of the crystal protein insecticidal specificity. Molecular Microbiology, vol. 4, p. 2087-2094. PMid:2089222. http://dx.doi. org/10.1111/j.1365-2958.1990.tb00569.x

DE BARJAC, H. and LECADET, MM., 1976. Dosage biochimiqu d'exotoxine thermostable de Bacillus thuringiensis d'après linhibition d'ARN-polymerase bateriennes. C.R. Academic Society, vol. 282, p. 2119-2122.

DE GUGLIELMO-CROQUER, Z., ALTOSAAR, I., ZAIDI, M. and MENÉNDEZ-YUFFÁ, A., 2010. Transformation of coffee (Coffea Arabica L. cv. Catimor) with the crylac gene by biolistic, without the use of markers. Brazilian Journal of Biology, vol. 70, no. 2, p. 387-393. http://dx.doi.org/10.1590/ S1519-69842010000200022

DE MAAGD, RA., BRAVO, A. and CRICKMORE, N., 2001. How Bacillus thuringiensis has evolved specific toxins to colonize the insect world. Trends Genetics, vol. 17, p. 193- 199. http:// dx.doi.org/10.1016/S0168-9525(01)02237-5

DIAS, SC., SAGARDOY, MA., SILVA, S. F. and DIAS, JMCS., 1999. Characterization and pathogenic evaluation of
Bacillus thuringiensis and Bacillus sphaericus isolates from Argentinean soils. Biological Control, vol. 44, no. 1, p. 59-71.

ESTRUCH, JJ., CAROZZI, NB., DESAI, N., DUCK, NB., WARREN, GW. and KOZIEL, MG., 1997. Transgenic plants: an emerging approach to pest control. Nature Biotechnology, vol. 15, p. 137-141. PMid:9035137. http://dx.doi.org/10.1038/nbt0297-137

FIUZA, LM., 1995. Étude des sites récepteurs et de la toxicité des $\delta$-endotoxine de Bacillus thuringiensis Berliner chez les larves de la pyrale du riz Chilo supressalis Walker. Montpellier: Université de Montpellier. 180 p. (Tese de Doutorado)

-, 2004. Receptores de Bacillus thuringiensis em insetos. Biotecnologia Ciência \& Desenvolvimento, vol. 32. p. 84-89.

GALLO, D., NAKANO, O., NETO, SS., CARVALHO, RPL., BAPTISTA, GC., BERTI FILHO, E., PARRA, JRP., ZUCCHI, RA., ALVES, SB., VENDRAMIM, JD., MARCHINI, LC., LOPES, JRS. and OMOTO, C., 2002. Entomologia Agrícola. Piracicaba: FEALQ. 920 p.

GREENE, GL., LEPPLA, NC. and DICKERSON, WA., 1976. Velvet bean caterpillar: a rearing procedure and artificial medium. Journal of Economic Entomology, vol. 69, p. 487-488.

GROCHULSKI, P., MASSON, L., BORISOVA, S., PUSZTAICAREY, M., SCHWARTZ, J., BROUSSEAU, R. and CYGLER, M., 1995. Bacillus thuringiensis CryIA(a) insecticidal toxin-crystal structure and channel formation. Journal of Molecular Biology, vol. 254, p. 447-464. PMid:7490762. http://dx.doi.org/10.1006/ jmbi.1995.0630

GOBATTO, V., GIANI, SG., CAMASSOLA, M., DILLON, AJP., SPECHT, A., BARROS, NM., 2010. Bacillus thuringiensis isolates entomopathogenic for Culex quinquefasciatus (Diptera: Culicidae) and Anticarsia gemmatalis (Lepidoptera: Noctuidae). Brazilian Journal of Biology, vol. 70, n. 4, p. 1039-1046. http:// dx.doi.org/10.1590/S1519-69842010000500018

HABIB, MEM. and ANDRADE, CFS., 1998. Bactérias entomapatogênicas. In ALVES, SB. Controle Microbiano de Insetos. São Paulo: FEALQ. p. 383-446.

HADDAD, ML., 1998. Utilização do Polo-PC para análise de Probit. In ALVES, SB. Controle Microbiano de Insetos. São Paulo: FEALQ. p. 999-1012.

HANSEN, BM. and HENDRIKSEN, NB., 2001. Detection of enterotoxic Bacillus cereus and Bacillus thuringiensis strains by PCR analysis. Applied and Environment Microbiology, vol. 67, p. 185-189. PMid:11133444. PMCid:92543. http://dx.doi. org/10.1128/AEM.67.1.185-189.2001

JOUZANI, GS., ABAD, AP., SEIFINEJADE, A., MARZBAN, R., KARIMAN, K. and MALEKI, B., 2008. Distribution and diversity of dipteran-specific cry and cyt genes in native Bacillus thuringiensis strains obtained from different ecosystems of Iran. Journal of Industrial Microbiology and Biotechnology, vol. 35, p. 83-94. PMid:7766065. http://dx.doi.org/10.1007/s10295-007-0269-6

KNAAK, N., FRANZ, AR., SANTOS, GF. and FIUZA, LM., 2010. Histopathology and the lethal effect of Cry proteins and strains of Bacillus thuringiensis Berliner in Spodoptera frugiperda JE Smith Caterpillars (Lepidoptera, Noctuidae). Brazilian Journal of Biology, vol. 70, n. 3, p. 677-684. http://dx.doi.org/10.1590/ S1519-69842010000300028

LAEMMLI, UK., 1970. Cleavage of structural proteins during the assembly of the head of bacteriophage T4. Nature, vol. 227, p. $680-685$. 
LEVY, SM., FALLEIROS, AMF., GREGÓRIO, EA., ARREBOLA, NR. and TOLEDO, LA., 2004. The larval midgut of Anticarsia gemmatalis (Hübner) (Lepidoptera: Noctuidae): light and electron microscopy studies of the epithelial cells. Brazilian Journal of Biology, vol. 64, no. 3B, p. 633-638. PMid:15620001.

LIAO, C., HECKEL, DG., and AKHURST, R., 2002. Toxicity of Bacillus thuringiensis insecticidal proteins for Helicoverpa armigera and Helicoverpa punctigera (Lepidoptera: Noctuidae), major pests of cotton. Journal Invertebrate Pathology, vol. 80, no. 1, p. 55-63. http://dx.doi.org/10.1016/S0022-2011(02)00035-6

LOPES, JA., ARANTES, OMN. and CENCI, MA., 2010. Evaluation of a new formulation of Bacillus thuringiensis israelensis. Brazilian Journal of Biology, vol. 70, no. 4, p. 1109-1113. http://dx.doi. org/10.1590/S1519-69842010000500029

LÓPEZ-PAZOS, SA., GÓMEZ, JEC. and SALAMANCA, JC., 2009. Cry1B and Cry3A are active against Hypothenemus hampei Ferrari (Coleoptera: Scolytidae). Journal of Invertebrate Pathology, vol. 101, p. 242-245. PMid:19465024. http://dx.doi. org/10.1016/j.jip.2009.05.011

MARROQUIN, LD., ELYASSNIA, D., GRIFFITTS, JS., FEITELSON, JS. and AROIAN, RV., 2000. Bacillus thuringiensis $(B t)$ Toxin Susceptibility and Isolation of Resistance Mutants in the Nematode Caenorhabditis elegans. Genetics, vol. 155, p. 1693-1699. PMid:10924467. PMCid:1461216.

MARTINS, JFS., CARBONARI, JJ. and VENDRAMIM, JD., 2004. Simulação do dano causado por larvas de Oryzophagus oryzae a cultivares de arroz irrigado. Ciência Rural, vol. 34, no. 3, p. 653-659. http://dx.doi.org/10.1590/S0103-84782004000300001

MASCARENHAS, RN., BOETHEL, DJ., LEONARD, BR., BOYD, ML. and CLEMENS CG., 1998. Resistance monitoring to Bacillus thuringiensis insecticides for Soybean Loopers (Lepidoptera: Noctuidae) collected from soybean and transgenic Bt cotton. Journal Economic Entomology, vol. 91, p. 1044-1050.

MONNERAT, RG., BATISTA, AC., MEDEIROS, PT., MARTINS, ES., MELATTI, VM., PRAÇA, LB., DUMAS, VF., MORINAGA, C., DEMO, C., GOMES, ACM., FALCÃO, R., SIQUEIRA, CB., SILVA-WERNECK, JO. and BERRY, C., 2007. Screening of Brazilian Bacillus thuringiensis isolates active against Spodoptera frugiperda, Plutella xylostella and Anticarsia gemmatalis. Biological Control, vol. 41, p. 291-295. http://dx.doi.org/10.1016/j. biocontrol.2006.11.008

MORALES, L., MOSCARDI, F., KASTELIC, JG., SOSA-GOMEZ, DR., PARO, FR. and SOLDORIO, IL., 1995. Suscetibilidade de Anticarsia gemmatalis Hübner e Chrysodeixis includens Walker (Lepidoptera: Noctuidae), a Bacillus thuringiensis Berliner. Anais Sociedade de Entomologia do Brasil, vol. 24, p. 593-598.

MOSCARDI, F. and CARVALHO, RCZ., 1993. Consumo e utilização de soja por Anticarsia gemmatalis Hübner. (Lepidoptera: Noctuidae) infectada, em diferentes estádios larvais, por seu vírus de poliedrose nuclear. Anais Sociedade Entomologia Brasileira, vol. 22, p. 267-280.

NAZARIAN, A., JAHANGIRI, R., JOUZANI, GS., SEIFINEJAD, A., SOHEILIVAND, S., BAGHERI, O., KESHAVARZI, M. and ALAMISAEID, K., 2009. Coleopteran-specific and putative novel cry genes in Iranian native Bacillus thuringiensis collection. Journal of Invertebrate Pathology, vol. 102, p. 101-109. PMid:19631215. http://dx.doi.org/10.1016/j.jip.2009.07.009
PANG, AS., GRINGORTEN, JL. and VAN-FRANKENHUYZEN, K., 2002. Interaction between Cry9Ca and two Cry1A deltaendotoxins from Bacillus thuringiensis in larval toxicity and binding to brush border membrane vesicles of the spruce budworm, Choristoneura fumiferana Clemens. FEMS Microbiology Letters, vol. 215, no. 1, p. 109-114. PMid:12393209.

PANIZZI, AR. and CORRÊA-FERREIRA, BS., 1997. Dynamics in the insect fauna adaptation to soybean in the tropics. Trends Entomology, vol. 1, p. 71-88.

PINTO, LMN. and FIUZA, LM., 2003. Distribuição de genes cry de Bacillus thuringiensis isolados de solos do Estado do Rio Grande do Sul, Brasil. Ciência Rural, vol. 33, no. 33, p. 699-702.

PINTO, LMN., AZAMBUJA, AO., DIEHL, E. and FIUZA, LM., 2003. Pathogenicity of Bacillus thuringiensis isolated from two species of Acromyrmex (Hymenoptera, Formicidae). Brazilian Journal Biology, vol. 63, no. 2, p. 301-6. PMid:14509852.

POLANCZYK, RA., DA SILVA, RFP. and FIUZA, LM., 2003. Screening of Bacillus thuringiensis isolates pathogenic to Spodoptera frugiperda (J. E. Smith) (Lepidoptera: Noctuidae). Arquivos Instituto Biológico, vol. 70, no. 1, p. 69-72.

SILVA, SMB., SILVA-WERNECK, JO., FALCÃO, R., GOMES, AC., FRAGOSO, RR., QUEZADO, MT., OLIVEIRA NETO, OB., AQUIAR, JB., DE SÁ, MFG., BRAVO, A. and MONNERAT, RG., 2004. Characterization of novel Brazilian Bacillus thuringiensis strains active against Spodoptera frugiperda and other insect pests. Journal Applied Entomology, vol. 128, p. 102-107. http:// dx.doi.org/10.1046/j.1439-0418.2003.00812.x

SILVA-WERNECK, JO. and ELLAR, DJ., 2008.Characterization of a novel Cry9Bb $\delta$-endotoxin from Bacillus thuringiensis. Journal of Invertebrate Pathology, vol. 98, no. 3, p. 320-328. PMid:18456277. http://dx.doi.org/10.1016/j.jip.2008.03.012

TAYLOR, R., TIPPETT, J., GIBB, G., PELLS, PIKE, D., JORDAN, L. and ELY, S., 1992. Identification and characterization of novel Bacillus thuringiensis delta-endotoxin entomicidal to coleopteran and lepidopteron larvae. Molecular Microbiology, vol. 6, p. 12111217. PMid:1588820. http://dx.doi.org/10.1111/j.1365-2958.1992. tb01560.x

URIBE, D., MARTINEZ, W. and CERÓN, J., 2003. Distribution and diversity of cry genes in native strains of Bacillus thuringiensis obtained from different ecosystems from Colombia. Journal Invertebrate Pathology, vol. 82, p. 119-127. http://dx.doi. org/10.1016/S0022-2011(02)00195-7

WANG, VW., KAHINDI, JHP., OLEMBO, NK. and OCHANDA, JO., 2003. Isolation and Characterization of Bacillus thuringiensis strains from soil samples from Kakamega and Machakos Districts in Kenya. Journal of Tropical Microbiology, vol. 2, p. 3-10.

WU, D., CAO, X.L., BAI, YY. and ARONSON, AI., 1991. Sequence of an operon containing a novel delta-endotoxin gene from Bacillus thuringiensis. FEMS Microbiology Letters, vol. 65 , p. $31-35$.

ZHONG, C., ELLAR, DJ., BISHOP, A., JOHNSON, C., LIN, S. and HART, ER., 2000. Characterization of a Bacillus thuringiensis delta-endotoxin which is toxic to insects in three orders. Journal Invertebrate Pathology, vol. 76, no. 2, p. 131-9. PMid:11023737. http://dx.doi.org/10.1006/jipa.2000.4962 
